\title{
PEREMPUAN, PENGELOLAAN KEUANGAN DAN EKONOMI KELUARGA
}

\author{
Ari Ani Dyah Setyoningrum ${ }^{1)}$, Kirtyana Nindita ${ }^{2)}$ \\ ${ }^{1)}$ Politeknik Maritim Negeri Indonesia \\ Jl. Pawiyatan Luhur I No. 1 Bendan Duwur Semarang \\ ${ }^{2)}$ Politeknik Maritim Negeri Indonesia \\ Jl. Pawiyatan Luhur I No. 1 Bendan Duwur Semarang \\ e-mail: $\underline{\text { ari@polimarin.ac.id }}{ }^{1)}, \underline{\text { k.nindita@gmail.com }}^{2)}$
}

\begin{abstract}
ABSTRAK
Perempuan dalam rumah tangga mempunyai berbagai peran. Rumah tangga dapat diartikan sebagai suatu organisasi yang paling kecil dalam masyarakat. Perempuan juga berperan penting dalam peningkatan kesejahteraan keluarga. Dalam menjalankan rumah tangga diperlukan keseimbangan dalam tata kelola, keteraturan dan konsep yang baik. Jika stabilitas rumah tangga terganggu, maka dapat mengakibatkan ketidaksinkronan dalam rumah tangga, sehingga berpengaruh pada kondisi ekonomi. Seiring dengan perkembangan dan kemajuan pembangunan, terjadi pergeseran peran perempuan, khususnya dari peranperan rumah tangga (domestic role) menjadi peran-peran yang lebih berorientasi pada masyarakat luas (public role), yaitu bekerja di luar rumah. Perempuan yang mencari nafkah dapat membantu kondisi ekonomi keluarga. Selain itu tingkat kemakmuran ekonomi suatu keluarga dipengaruhi oleh pengelolaan keuangan yang baik. Pengelolaan keuangan yang dimaksud berupa perencanaan keuangan dan pengendalian hutang. Perencanaan keuangan yang baik, akan mendisiplinkan pengeluaran rumah tangga, sehingga kondisi ekonomi keluarga menjadi baik. Sedangkan pengendalian hutang merupakan salah satu wujud kontrol dalam keuangan. Penelitian ini menggunakan metode penelitian kuantitatif dengan alat analisis SmartPLS 3.0. hasil peneltian ini menyatakan bahwa variabel peran perempuan dalam mencari nafkah tidak berpengaruh terhadap ekonomi keluarga, sedangkan peran perempuan dalam pengelolaan keuangan berdimensi perencanaan dan pengendalian hutang berpengaruh signifikan terhadap ekonomi keluarga.
\end{abstract}

Kata kunci: ekonomi keluarga, peran perempuan, pengelolaan keuangan

\section{ABSTRACT}

Women in the household have various roles. Household can be defined as the smallest organization in society. Women also play an important role in improving family welfare. In running a household, it is necessary to have a balance in governance, order and good concepts. If household stability is disturbed, it can result in asynchrony in the household, thus affecting economic conditions. Along with the development and progress of development, there has been a shift in the role of women, particularly from domestic roles to public roles that are more oriented towards the wider community, like working outside the home. Women who earn a living can help the household's economic condition. In addition, the level of economic prosperity of a family is influenced by good financial management. Financial management is in the form of financial planning and debt control. Good financial planning will discipline household expenses, so that the household's economic condition is good. Meanwhile, debt control is a form of control in finance. This study uses quantitative 
research methods with the SmartPLS 3.0 analysis tool. The results of this study state that the variable role of women in earning a living does not affect the household economy, while the role of women in financial management with the dimensions of planning and debt control has a significant effect on the household economy.

Keywords: family economy, the role of women, financial management,

\section{Pendahuluan}

Perkembangan zaman modern seperti saat ini, perempuan dalam rumah tangga berperan penting dalam peningkatan kesejahteraan keluarga. Kesetaraan kedudukan lakilaki dan wanita menjadi kunci yang penting dalam kehidupan keluarga. Kesetaraan gender telah menjadi isu yang penting di seluruh dunia sejak beberapa tahun ini. Tidak hanya di Indonesia, namun juga di berbagai dunia, isu gender menjadi wacana yang berkembang untuk diselesaikan.

Rumah tangga dilihat dari sudut pandang yang sempit (kehidupan di rumah) maupun dari sudut pandang yang luas (rumah tangga perusahaan maupun rumah tangga negara) kesemuanya memerlukan tata kelola yang baik, teratur dan terkonsep [1]. Rumah Tangga dapat diartikan sebagai suatu kumpulan dari masyarakat terkecil yang terdiri dari pasangan suami istri, anak-anak, mertua, dan sebagainya [2]. Rumah tangga dapat diartikan sebagai suatu organisasi yang paling kecil dalam masyarakat.

Dalam menjalankan rumah tangga, maka diperlukan keseimbangan dalam tata kelola, keteraturan dan konsep dalam berumah tangga yang baik. Jika salah satu dari ketiga hal tersebut tidak terpenuhi maka stabilitas rumah tangga pasti akan terganggu dan dapat mengakibatkan ketidaksinkronan baik untuk rumah tangga dalam artian kehidupan berumahtangga, rumah tangga perusahaan maupun rumah tangga negara [1]. Dengan tingkat penghasilan masyarakat yang rendah, maka peran perempuan sangat penting dalam mengatur pemenuhan kebutuhan keluarga.

Seiring dengan perkembangan dan kemajuan pembangunan, terjadi pergeseran peran wanita, khususnya dari peran-peran rumah tangga (domestic role) menjadi peran-peran yang lebih berorientasi pada masyarakat luas (public role), yaitu bekerja di luar rumah. Sebagai konsekuensinya terjadi peran ganda wanita [3]. Peranan perempuan di luar keluarga meliputi usaha untuk mencari nafkah seperti bekerja secara formal atau informal seperti berwirausaha.

Pengelolaan keuangan berperan sangat penting dalam ekonomi keluarga. Tingkat kemakmuran ekonomi suatu keluarga dipengaruhi oleh pengelolaan keuangan yang baik. Pengelolaan keuangan yang dimaksud berupa perencanaan keuangan dan pengendalian hutang. Perencanaan keuangan yang baik, akan mendisiplinkan pengeluaran rumah tangga, sehingga kondisi ekonomi keluarga menjadi baik. Sedangkan pengendalian hutang merupakan salah satu wujud kontrol dalam keuangan. Penelitian ini bertujuan untuk memberikan bukti empiris tentang peran perempuan dalam mencari nafkah, pengelolaan keuangan dalam dimensi perencanaan keuangan dan pengendalian hutang terhadap kondisi ekonomi keluarga.

\section{Landasan Teori dan Pengembangan Hipotesis}

\subsection{Peran Perempuan}

Peran perempuan dalam keluarga merupakan peranan yang dilaksanakan karena menduduki posisi dalam masyarakat. Secara umum perempuan memiliki tiga fungsi utama yang sangat berkaitan dengan kedudukan dan peran perempuan yaitu fungsi reproduksi, fungsi sosialisasi dan fungsi produksi. 
Fungsi reproduksi sering dihubungkan dengan hak dan kewajiban sekaligus sebagai simbol kelebihan dan kelemahan perempuan. Fungsi sosialisasi berkaitan erat dengan fungsi dan tanggung jawabnya dalam mempersiapkan anak-anaknya masuk ke dalam pergaulan masyarakat luas, dimana pengasuhan dan pendidikan boleh dilakukan oleh orang lain tetapi tanggung jawabnya tetap terletak pada seorang ibu. Fungsi produksi berkaitan dengan fungsi ekonomis perempuan, misalnya sebagai perempuan yang bekerja dan memberikan kontribusi ekonomi bagi keluarganya melalui pendapatan yang diperoleh. Sejalan dengan kemajuan zaman, peningkatan kesempatan dan pendidikan memungkinkan perempuan tidak saja berperan ekonomis secara tidak langsung, tetapi juga dapat secara langsung menerima hasil baik berupa uang ataupun barang sebagai imbalan baginya dalam melakukan pekerjaan ekonomi [4].

Tatanan kehidupan manusia yang didominasi kaum laki-laki atas kaum perempuan sudah menjadi sejarah perjalanan manusia. Dalam kondisi itu, perempuan ditempatkan sebagai manusia kelas dua yang berada di bawah superioritas laki-laki, perempuan sebagai perlengkap untuk kepentingan laki-laki, sehingga banyak perempuan yang hanya pada ranah domestik, sedangkan laki-laki di ranah publik. Kini persepsi itu mulai luntur, sebab sinergisitas hubungan antara suami dengan istri harus dibangun dengan baik [5].

Optimalisasi untuk membangun civil society, dengan memperjuangkan ruang publik sebagai tempat untuk semua warga bangsa dalam mengembangkan kompetensinya, memberi peluang dan kesempatanya bagi pemenuhan kebutuhan agar perempuan dapat mencapai aktualisasi dirinya. Ini semua dapat direalisasikan melalui kegiatan-kegiatan penyadaran dengan membongkar mitos, terutama mengubah cara pandang dan pola pikir kita, baik kaum laki-laki maupun perempuan terhadap prinsip-prinsip demokrasi yang menjamin kesetaraan, hak asasi manusia, supermasi hukum dan keadilan.

Menurut Aswiyati dalam [5] keikutsertaan perempuan dalam usaha meningkatkan kesejahteraan keluarga merupakan perwujudan dari perannya secara dinamis dari kedudukan dan status sosial perempuan dalam suatu sistem sosial tempat perempuan tersebut berada. Ihromi membedakan peranan dan kedudukan perempuan atas dua bagian, yaitu: (1) Peranan dan kedudukannya didalam keluarga sebagai tenaga kerja domestik labor yang berhubungan dengan masalah-masalah mengurus rumah tangga, dan (2) Peranan dan kedudukannya di luar keluarga meliputi usaha untuk mencari nafkah dan memperoleh penghasilan keluarga serta jangkauan sosial terhadap berbagai kegiatan di luar rumah tangga.

Berdasarkan uraian di atas, memperlihatkan bahwa eksistensi perempuan yang dapat dipahami oleh berbagai pihak, yang tentu saja tidak melupakan peran perempuan dalam keluarga, seperti peran sebagai istri, pendampingan suami, kendali keluarga, ibu atau orang tua, pendidik, pencari nafkah sekaligus sebagai manajer keuangan dalam keluarga.

Variabel peran perempuan dalam penelitian ini menggunakan peran dalam usaha meningkatkan kesejahteraan keluarga dengan mencari nafkah dan memperoleh penghasilan keluarga. Peran ini penting untuk diteliti terkait dengan kondisi ekonomi rumah tangga.

\subsection{Pengelolaan Ekonomi Keluarga}

Pengelolaan ekonomi keluarga adalah tindakan untuk merencanakan, melaksanakan, memonitor, mengevaluasi, dan mengendalikan perolehan dan penggunaan sumber-sumber ekonomi keluarga khususnya keuangan agar tercapai tingkat pemenuhan kebutuhan seluruh anggota keluarga secara optimum dan memastikan adanya stabililtas dan pertumbuhan ekonomi keluarga [6]

Pengelolaan keuangan keluarga memegang peranan yang sangat penting dalam menentukan tingkat kemakmuran ekonomi sebuah keluarga. Pengelolaan keuangan yang dimaksud dalam hal ini adalah perencanaan keuangan. Dalam sebuah perencanaan keuangan yang baik akan terdapat daftar pemasukan dan pengeluaran uang secara terperinci. Dengan adanya daftar yang terperinci, orang tua sebagai manager keuangan keluarga akan dapat mendeteksi setiap terjadi penyimpangan rencana keuangan. Perencanaan keuangan sebagai proses mencapai tujuan hidup seseorang melalui manajemen keuangan secara terencana [7] 
[8] juga menyebutkan bahwa ada banyak strategi yang dapat ditempuh guna menyiasati keterbatasan keuangan rumah tangga akibat kenaikan harga BBM, antara lain pengurangan pengeluaran di pos-pos strategis seperti pendidikan, kesehatan, termasuk pengurangan kuantitas dan kualitas pangan keluarga dan melakukan manajemen utang. Dalam mengelola cara yang ditempuh, untuk itu diperlukan pengelolaan keuangan rumah tangga agar lebih efisien dalam setiap pengeluaran, karena persoalan kecil bisa menjadi besar bila tidak diatasi dan diselesaikan dengan bijak apalagi kalau persoalan yang menyangkut uang.

\subsection{Keluarga dan Ekonomi}

Keluarga didefinisikan sebagai unit terkecil dari organisasi sosial. Bagian dalam keluarga saling bekerja sama untuk melaksanakan kegiatan guna mencapai tujuan yang sama. Keluarga dibentuk dengan tujuan untuk mencapai kepuasan tingkat tinggi. Tujuan kelurga bukan hanya untuk mencapai kesejahteraan material, namun juga cinta, keceriaan, kesehatan dan pengasuhan [9]

Keluarga adalah institusi pertama bagi anak-anak yang melayani beberapa fungsi edukatif seperti pendidikan moral, sosial, agama, emosional anak dan lain sebagainya. Keluarga sebagai dasar unit masyarakat memainkan peran penting dalam kehidupan seorang individu. Karena dalam keluarga tersebutlah anak-anak mendapat didikan dan bimbingan. Institusi sakral (keluarga/rumah tangga) ini selalu menjadi pusat perhatian, bukan saja karena berbagai keistimewaan di dalamnya, tetapi juga karena nilai penting sebagai satuan masyarakat terkecil yang bertanggungjawab atas terlaksananya pembangunan nasional, sehingga keluarga/rumah tangga merupakan karier yang sebenarnya dari seorang manusia. Karena pada akhirnya keberhasilan dan kesuksesan rumah tangga akan diukur dari karier berkeluarganya, yang merupakan awal dan akhir kariernya [7].

Disatu sisi rumah tangga adalah harapan bagi masa depan, tetapi disisi lain keluarga menuntut tanggung jawab. Kunci keberhasilannya adalah bagaimana kemampuan menyelaraskan antara tanggung jawab dengan harapan masa depan. Hanya dengan cara itulah akan dinikmati kebahagiaan yang lengkap dan sempurna, yang hanya dapat dinikmati oleh mereka menciptakan keluarga sukses [10]. Dari berbagai aspek yang tercakup dalam pendidikan anak di lingkungan keluarga, aspek ekonomi memiliki pengaruh yang besar pada proses pendewasaan anak.

Masalah utama dalam kajian ekonomi keluarga adalah kelangkaan, yakni kondisi yang terjadi akibat keluarga tidak memiliki sumber daya yang cukup untuk menghasilkan segala sesuatu yang seharusnya (ingin) dimiliki keluarga. Sumber daya dalam konteks ekonomi rumah tangga dibagi menjadi dua jenis, yaitu sumber daya fisik (terdiri dari sumber daya alam dan sumber daya finansial), dan sumber daya manusia yaitu waktu, keahlian, dan energi [9].

\section{Metode Penelitian}

\subsection{Metode dan Variabel Penelitian}

Penelitian ini dilakukan dengan metode penelitian kuanlitatif. Penelitian kuantitatif adalah penelitian yang digunakan untuk menemukan pengetahuan dengan menggunakan data berupa angka sebagai alat menganalisis keterangan mengenai apa yang ingin diketahui. Penelitian ini bertujuan untuk memberikan bukti empiris tentang peran perempuan, pengaruh pengelolaan keuangan berdasarkan perencanaan keuangan dan pengendalian hutang terhadap ekonomi keluarga. Jenis penelitian ini adalah penelitian korelasional yang menguji hubungan antar variabel. Jenis data yang digunakan adalah data kuantitatif dengan menggunakan kesioner.

Variabel yang digunakan dalam penelitian ini terdiri dari variabel independen dan variabel dependen. Variabel independen yang digunakan adalah peran perempuan, pengelolaan keuangan berdimensi perencanaan keuangan dan pengelolaan keuangan 
berdimensi pengendalian hutang. Sedangkan variabel dependen dalam penelitian ini adalah ekonomi keluarga.

\subsection{Outer Model}

Cara evaluasi outer model adalah dengan menggunakan evaluasi validitas konstruk dan reabilitas konstruk. Pengujian validitas dilakukan dengan dua cara yaitu:

1. convergent validity. Loading faktor mempunyai nilai lebih dari 0.7 untuk confirmatory research dan 0.6 untuk explanotory research [11].

2. discriminant validity dinilai berdasarkan cross loading pengukuran konstruk. Jika nilai korelasi kontruk lebih besar dari ukuran konstruk lain, maka konstruk laten mampu memprediksi validitas yang baik. Selain itu dapat juga dilihat dari nilai AVE dari setiap konstruk. Nilai AVE harus lebih besar dari 0.05 [11]. Sedangkan reabilitas konstruk dinilai dari composite reability yang dapat dievaluasi dengan dua macam ukuran yaitu internal consistency dan cronbach's alpha [11]. Konstruk dinyatakan reliable jika memilki nilai composite reability dan cronbach's alpha di atas 0.7 .

\subsection{Inner Model}

Inner model menggambarkan hubungan antara variabel laten pada teori subtantif. Model struktural dievaluasi dengan menggunakan R-square untuk konstruk dependen. Dalam menilai model dengan PLS dimulai dengan melihat R-square untuk setiap variabel laten independen. Intrepretasinya sama dengan intrepretasi pada regresi[11].

\subsection{Pengujian Hipotesis}

Untuk pengujian hipotesis dengan menggunakan SmartPLS dilakukan dengan bootstraping. Selanjutnya dilakukan analisis pada tabel path coefficients yang merupakan output setelah dilakukan proses bootrapping. Pada tabel path coefficients perlu dilihat nilai original sampel (O) yang menunjukkan signifikansi hubungan kontruk. Pengaruh antar variabel dianggap signifikan pada tingkat 5\%. Kriteria pengujian dalam penelitian ini ditentukan sebagai berikut:

a. Jika nilai t-statistic $>\mathrm{t}$-tabel, maka hipotesis diterima.

b. Jika nilai t-statistic < t-tabel, maka hipotesis ditolak

\section{Hasil dan Pembahasan}

\subsection{Evaluasi Outer Model}

Evaluasi outer model dilakukan untuk mengukur validitas dan reabilitas model yang digunakan dalam penelitian. Evaluasi outer model dalam penelitian ini dilakukan dengan melihat nilai pada validitas convergent dan discriminat dari indikator pembentuk konstruk laten. Reabilitas data diukur dengan melihat nilai cronbach's alpha dan nilai composite reliability. Hasil pengujian outer model didapat nilai untuk semua indikator peran, perencanaan keuangan, pengendalian hutang dan ekonomi mempunyai nilai di atas 0.6 . artinya bahwa semua indikator variabel perencanaan keuangan, pengendalian hutang dan ekonomi telah layak untuk digunakan dalam analisis selanjutnya.

Pengujian selanjutnya adalah pengujian discriminant validity dengan menggunakan nilai cross loading. Suatu indikator dinyatakan memenuhi discriminant validity apabila nilai cross loading indikator pada variabelnya adalah yang terbesar dibandingkan pada variabel lainnya. Berdasarkan hasil pengolahan, dapat dinyatakan bahwa indikator-indikator yang digunakan dalam penelitian ini telah memiliki discriminant validity yang baik dalam menyusun variabelnya masing-masing. Selain itu Nilai AVE untuk setiap variabel telah memiliki nilai $>0.5$. Dengan demikian dapat disimpulkan bahwa data telah memiliki nilai discriminat validity yang baik. 


\subsection{Pengujian Reabilitas data}

Pengujian reabilitas data dengan menggunakan Composite Reliability yang merupakan bagian untuk menguji nilai reliabilitas indikator-indikator pada suatu variabel. Suatu variabel dapat dinyatakan memenuhi composite reliability apabila memiliki nilai composite reliability > 0,7. Berikut ini adalah nilai composite reliability dari masing-masing variabel yang digunakan dalam penelitian ini:

Tabel 1 Composite Reliability

\begin{tabular}{|l|l|}
\hline Variabel & Composite Reliability \\
\hline Peran & 0.810 \\
\hline Perencanaan & 0.853 \\
\hline Pengendalian hutang & 0.709 \\
\hline Ekonomi & 0.754 \\
\hline
\end{tabular}

Dari tabel di atas, dapat diketahui bahwa nilai composite reliability semua variabel penelitian >0,7. Hasil ini menunjukkan bahwa masing-masing variabel telah memenuhi composite realibility. Pengujian realibilitas dengan composite reability yang telah dilakukan dapat diperkuat dengan menggunakan nilai cronbach alpha. Suatu variabel dapat dinyatakan reliabel berdasarkan cronbach alpha apabila memiliki nilai >0,7. Berdasarkan hasil pengolahan data diketahui bahwa nilai cronbach alpha semua variabel penelitian >0,7. Sehingga dapat disimpulkan bahwa semua variabel memiliki tingkat realibilitas yang tinggi.

\subsection{Evaluasi Inner Model}

Nilai $\mathrm{R}$ square digunakan untuk mengukur seberapa banyak variabel eksogen berpengaruh terhadap variabel endogen. Nilai $\mathrm{R}$ square 0,75 menunjukkan bahwa model kuat, nilai $\mathrm{R}$ square 0,5 menunjukkan bahwa model moderate dan nilai 0,25 menunjukkan bahwa model lemah.

Tabel 2 Nilai R Square

\begin{tabular}{|l|l|l|}
\hline & R Square & R Square Adjustment \\
\hline Perekonomian & 0.620 & 0.602 \\
\hline
\end{tabular}

Hasil uji inner model menunjukkan bahwa nilai $\mathrm{R}$ square adjustment adalah sebesar 0,602. Artinya bahwa model penelitian ini mempunyai model moderate. Varibel peran perempuan, pengelolaan berdimensi perencanaan keuangan dan pengendalian hutang mempunyai pengaruh 0,602 atau $60,2 \%$ terhadap variabel ekonomi keluarga. Sedangkan $39,8 \%$ jelaskan oleh variabel lainnya yang tidak berada dimodel penelitian ini.

\subsection{Uji Hipotesis}

Uji hipotesis dilihat dari nilai part coefficient. Part coefficient digunakan untuk melihat seberapa kuat pengaruh variabel independen dengan variabel dependen. Hasil path coefficient dapat dilihat pada tabel di bawah ini:

Tabel 3 Path Coefficients

\begin{tabular}{|l|c|c|c|c|c|}
\hline \multicolumn{1}{|c|}{ Variabel } & Original Sample & Sample Mean & Standard Deviasi & T Statistic & P Values \\
\hline Peran & 0.040 & 0.054 & 0.093 & 0.427 & 0.670 \\
\hline Perencanaan & 0.478 & 0.469 & 0.150 & 3.190 & 0.002 \\
\hline Pengendalian & 0.488 & 0.503 & 0.101 & 4.840 & 0.000 \\
\hline
\end{tabular}

Uji hipotesis pada penelitian ini dilakukan dengan melihat nilai $T$-Statistics dan nilai $P$ Values. Pada path coefficient juga dapat dilihat nilai orginal sample $(\mathrm{O})$ yang menunjukkan terjadinya hubungan positif atau negatif dari suatu konstruk. Hipotesis penelitian dapat 
dinyatakan diterima apabila nilai $P$-Values $<0,05$. Dari data di atas dapat disimpulkan bahwa variabel pengelolaan keuangan berdimensi perencanaan keuangan dan pengeloaan keuangan berdimensi pengawasan keuangan mempunyai $\mathrm{P}$ values di bawah 0,05 , artinya bahwa variabel pengelolaan keuangan berdimensi perencanaan keuangan dan pengeloaan keuangan berdimensi pengawasan keuangan berpengaruh terhadap ekonomi keluarga.

\subsection{Pembahasan}

\section{A. Pengaruh Peran Perempuan Terhadap Ekonomi Keluarga.}

Peran prempuan dalam penelitian ini berkaitan keikutsertaan dalam usaha meningkatkan kesejahteraan keluarga. Perempuan yang bekerja dan memperoleh penghasilan merupakan perwujudan dari perannya yang dinamis dalam sistem sosial. Hasil penelitian ini menunjukkan bahwa peran perempuan tidka berpengaruh signifikan terhadap ekonomi keluarga. Artinya bahwa peran perempuan dalam mencari nafkah kurang signifikan berpengaruh terhadap kondisi ekonomi keluarga.

Penyebab dari tidak berpengaruhnya peran perempuan dalam ekonomi keluarga dikarenakan perempuan yang mencari nafkah dalam rumah tangga, tidak berperan sebagai pencari nafkah utama. Mayoritas perempuan bekerja karena ingin mendapatkan penghasilan tambahan yang dapat digunakan untuk membantu ekonomi keluarga. Namun tidak sebagai pencari penghasilan utama. Laki-laki atau suami masih berperan dominan sebagai pencari nafkah. Sehingga kondisi ekonomi keluarga lebih bergantung pada penghasilan suami.

Penelitian ini sesuai dengan penelitian [12] yang menyatakan bahwa perempuan pencari nafkah hanya berperan sebagai subtitusi bagi laki-laki atau suami dalam rumah tangga. Pembagian kerja sebagai pencari nafkah masih didominasi oleh kaum laki. Hasil penelitian [13] juga menyatakan bahwa masih kuatnya nilai budaya patriarki pada masyarakat menyebabkan perempuan kurang mendapatkan akses aktivitas dan kontrol dalam pencarian nafkah. Namun penelitian ini tidak sesuai dengan hasil penelitian yang dilakukan [14] yang menyatakan bahwa perempuan berperan dalam meningkatkan ekonomi keluarga.

\section{B. Pengaruh Pengelolaan Keuangan Berdimensi Perencanaan Terhadap Ekonomi Keluarga.}

Pengelolaan keuangan mempunyai peran yang sangat penting terhadap ekonomi sebuah keluarga. Pengelolaan keuangan yang baik akan membuat kondisi ekonomi keluarga menajdi baik. Begitu pula sebaliknya, jika pengelolaan keuangan tidak baik, maka dapat dipastikan kondisi ekonomi tidak baik/buruk. Pengelolaan keuangan berdimensi perencanaan berpengaruh signifikan terhadap ekonomi keluarga. Dalam perencanaan keuangan yang baik, pengeluaran belanja maupun pemasukan dari pendapatan keluarga dapat terkendali.

Perencanaan keuangan sebagai proses mencapai tujuan hidup seseorang melalui manajemen keuangan secara terencana [7]. Responden menyatakan bahwa mereka selalu membuat perencanaan dalam pengeluaran belanjanya. Hal ini penting untuk bisa mengendalikan belanja rumah tangga yang cukup banyak. Kondisi ekonomi global saat ini juga membuat kondisi ekonomi keluarga menjadi sulit. Istri harus mampu mengontrol belanja dengan baik, karena penghasilan dalam keluarga cenderung tetap bahkan menurun. Sedangkan harga barang kebutuhan meningkat cukup banyak.

Pengeluaran belanja yang sesuai dengan perencanaan akan membuat kondisi ekonomi keluarga menjadi lebih stabil. Bila istri melakukan pengeluaran tanpa perencanaa yang baik, maka mengakibatkan pengeluaran menjadi tidak terkontrol, sehingga dapat memperbutuk kondisi ekonomi keluarga. Istri harus mampu membedakan antara kebutuhan dan keinginan, sehingga pengeluaran yang sifatnya tidak wajib tidak akan banyak dikeluarkan. Dengan disiplin menerapkan perencanaan keuangan rumah tangga, maka kemungkinan kondisi keuangan akan baik. 
Hasil penelitian ini sesuai dengan penelitian yang telah dilakukan oleh beberapa peniliti sebelumnya. [7] menyatakan bahwa dalam peneuhan kebutuhan dan sumber daya rumah tangga diperlukan pengelolaan ekonomi yang baik dengan cara membuat perencanaan keuangan. Perencanaan keuangan penting dilakukan agar dapat mendisiplinkan langkah dalam pengendalian diri dan mempersiapkan kondisi keuangan pada masa depan. Penelitian [1] juga menyatakan bahwa perempuan lebih mampu mengendalikan kebutuhan rumah tangga serta mampu membuat suatu perencanaan-perencanaan anggaran yang diperlukan secara sederhana.

Perempuan dinilai mampu untuk membuat perencanaan keuangan dalam keluarga. Perencanaan anggaran diperlukan secara sederhana diperlukan untuk mencapai suatu kepuasaan tersendiri serta untuk mencegah perselisihan di dalam rumah tangga. Kemampuan perempuan dalam perencanaan keuangan dibuktikan oleh penelitian [13] yang menyatakan bahwa istri dilibatkan pada pengelolaan keuangan karena adanya stereotipe yang menyatakan bahwa perempuan lebih mampu mengatur keuangan dari pada laki-laki.

\section{Pengaruh Pengelolaan Keuangan Berdimensi Pengendalian Hutang Terhadap Ekonomi Keluarga.}

Pengelolaan keuangan berdimensi pengendalian hutang berpengaruh terhadap ekonomi keluarga. Hutang biasanya dilakukan apabila ada pengeluaran lebih besar dari pada pendapatan yang dimiliki. Keputusan pengambilan hutang harus disepakati oleh suami dan istri. Hutang juga timbul akibat ketidakmampuan di dalam mengendalikan uang akan berdampak terhadap kesulitan ekonomi. Pengendalian hutang lebih ditekankan pada penghindaran hutang dari para kreditur maupun penggunaan kartu kredit.

Perempuan dalam rumah tangga atau istri harus mampu mengendalikan diri agar tidak terjerat dalam hutang. Istri harus melihat setiap kebutuhan dalam rumah tangganya dengan baik. Selain itu kesadaran akan pentingnya kondisi ekonomi yang bebas dari hutang juga berpengaruh terhadap kondisi psikologis anggota keluarga. [1] menyatakan bahwa bentuk praktik akuntansi dalam rumah tangga merupakan suatu skema dalam penghindaran hutang terhadap para kreditur maupun pemakaian kartu kredit yang berlebihan sehingga peran istri (perempuan) sangatlah penting untuk melihat setiap kebutuhan-kebutuhan apa saja yang harus diperlukan dalam rumah tangga.

Pengendalian hutang juga diperkuat dengan adanya komunikasi antara suami dan istri. Istri harus mampu mengkomunikasikan kepada suami bahwa jerat hutang dapat merusak ekonomi keluarga. Banyak keluarga yang rusak akibat hutang yang sudah menumpuk. Sehingga perceraian dan masa depan anak menjadi rusak akibat hutang tersebut. Pemenuhan kebutuhan keluarga harus cukup dari pendapatan suami dan istri. Apabila harus memutuskan untuk berhutang, maka harus ada dana cadangan yang memang digunakan untuk membayar hutang.

[15] menyatakan bahwa manajemen kredit keluarga mempunyai pengaruh yang penting terhadap kesejahteraan keluarga. Keluarga muda sudah baik dalam melakukan penghematan, serta sudah dapat menyisihkan sebagian pendapatannya untuk dapat membayar hutang kredit tepat waktu. Keluarga muda relatif masih terbatas dalam hal pendapatan namun kebutuhan rumah tangganya relatif lebih besar dari pendapatan, sehingga dihadapkan pada suatu kondisi agar dapat menghemat pengeluaran rumah tangga untuk dapat membayar hutang.

\section{Kesimpulan}

Berdasarkan hasil penelitian yang telah dilakukan, maka dapat diambil kesimpulan sebagai berkut:

1. Variabel peran perempuan dalam mencari nafkah tidak berpengaruh terhadap ekonomi keluarga, sedangkan peran perempuan dalam pengelolaan keuangan berdimensi perencanaan dan pengendalian hutang berpengaruh signifikan terhadap ekonomi keluarga. 
2. Hasil R-square menunjukkan nilai sebesar 0,602. Artinya bahwa variabel peran perempuan dalam nafkah, peran perempuan dalam pengelolaan keuangan berdimensi perencanaan dan pengendalian hutang mempunyai pengaruh sebesar 60, $2 \%$ terhadap ekonomi keluarga.

\section{DAFTAR PUSTAKA}

[1] N. E. Setiowati, "Perempuan, Strategi Nafkah dan Akuntansi Rumah Tangga," pp. 298-304, 2016.

[2] S. N. Bakry, Kunci Keutuhan Rumah Tangga. Jakarta: Pedoman Ilmu Jaya, 1993.

[3] A. Indrayati, "Peranan Wanita Dalam Perberdayaan Ekonomi Lokal (Studi Kasus Tentang Pola Ruang Belanja Wanita Di Daerah Pinggiran Kota Semarang)," Jur. Geogr. FIS UNNES, vol. 7, no. 2, pp. 88-102, 2010.

[4] D. H. Forddanta, "Peranan Wanita Dalam Menunjang Ekonomi Keluarga Miskin Diukur Dari Sisi Pendapatan," Universitas Diponegoro, 2012.

[5] F. Munawwarah, "Studi Tingkat Partisipasi Perempuan Dalam Meningkatkan Perekonomian Keluarga Menurut Perspektif Ekonomi Islam,” Universitas Islam Negeri Ar Raniry, 2018.

[6] K. M. Kalsel, "Pengelolaan Ekonomi Rumah Tangga," 2010. [Online]. Available: http://komunitasmkkalsel.blogspot.com/2010/12/pengelolaan-ekonomi-rumah-tangga.html.

[7] F. N. Masithoh, H. Wahyono, and C. Wardoyo, "Konsep pengelolaan ekonomi rumah tangga dalam memajukan kesejahteraan," Natl. Conf. Econ. Educ., pp. 530-542, 2016.

[8] Damayanti, "Analisis Strategi Pengelolaan Keuangan Rumah Tangga Pasca Kenaikan Harga Bahan Bakar Minyak," pp. 117-126, 2010.

[9] S. Doriza, Ekonomi Keluarga. Bandung: PT. Remaja Rosdakarya, 2015.

[10] H. K. Wibawa, Perencanaan Keuangan Keluarga. Jakarta: Salemba Empat, 2003.

[11] I. Ghozali and H. Latan, Partial Least Squares Konsep, Teknik dan Aplikasi Menggunakan Smart PLS 3.0 Untuk Penelitian Empiris, 2nd ed. Semarang: Badan Penerbit Universitas Diponegoro, 2014.

[12] A. Kristina, "Partisipasi Perempuan Dalam Perbaikan Perekonomian Keluarga dan Masyarakat," Pamator, vol. 3, pp. 69-75, 2010.

[13] S. Widodo, "Analisis peran perempuan dalam usahatani tembakau," vol. 6, no. 2, pp. 148-153, 2009.

[14] S. Reskianti, "Peran Istri Dalam Upaya Meningkatkan Perekonomian Rumah Tangga Ditinjau Dari Ekonomi Islam (Studi Kasus Pada Pedagang Di Pasar Sentral Kab. Bulukumba)," Universitas Islam Negeri Alaudin, 2017.

[15] I. T. Raharjo, H. Puspitawati, and D. Krisnatuti, "TekananEkonomi, Manajemen Keuangan, dan Kesejahteraan Pada Keluarga Muda,” vol. 8, no. 1, pp. 38-48, 2015. 